\title{
Comparative Study of Leading Cruise Lines' Sustainability Practices and Environmental Stewardship in Contribution to SDGs' Sea and Water Conservation Goal
}

\author{
Hesam Pakbeen $^{1}$
}

\begin{abstract}
Cruise vacation is one of the fastest growing segments of tourism industry. Cruise Lines International Association (CLIA) reports that in 2017 nearly 26 million ocean cruise passengers were carried globally, which is expected to reach 27.2 million passengers in 2018. In terms of environmental impacts, however, the growth of the industry has raised increased concerns. Accordingly, environmental regulations, policies and commitments urge the cruise lines to conduct sustainability practices and report on their environmental stewardship. In contribution to UN's Sustainable Development Goals (SDGs), the cruise industry can be a significant enabler for positive impact, distinctly on environmental goals. The present paper reviews environmental stewardship and practices of the leading cruise lines in contribution to goal No.14 of SDGs, referring to "life below water". The objective of this study is to investigate how sustainability strategies and practices of leading cruise companies responded to water and sea conservation goal. The study includes an outline of cruise industry, growth and impacts following by exploratory review of sustainability and corporate responsibility reporting of major cruise lines. The findings of the research are based on evaluation and comparison of (1) practices and actions, (2) strategies and goal settings, and (3) cooperation and partnership of cruise lines, in regard with water and sea conservation goal of SDGs.
\end{abstract}

Keywords: Cruise industry, Environmental stewardship, SDGs (Sustainable Development Goals), Sea and Water conservation

\section{Cruising and Impacts}

Cruise travel is one of the largest segments of tourism and hospitality industry and attracting increasing interest from holiday makers. It is also the fastest growing category of tourism industry, experiencing an average growth rate of $7.5 \%$ annually since 2008 (Cruise Market Watch, 2018a). CLIA: Cruise Lines International Association (2018a) reports over 27 million cruise passengers in 2018 are expected to travel globally that demonstrates a dramatic increase compared to 7 million passengers in 2000. CLIA's report also shows that the demand for cruising only from 2011-2016 has increased by $20.5 \%$. Due to the steadily rising demand from travel makers, a significant number of new cruise ships are on order. In 2018 and 2019, 17 and 25 new ships will be built respectively in different shipyards. For example, Meyer Group Shipyards (including Meyer Werft yard in Germany and Meyer Turku yard in Finland) have a total number of 21 ships in their order books from 2018 to 2024.

By the rise of interest in cruising and development of the cruise travel, the impacts of the 
industry are growing in scale (Jones et al., 2016; Aguirre \& Brida 2008). That includes economic, social and environmental impacts. In regard with economic impacts, for example, CLIA (2017a) reports that in 2016 cruise expenditures generated nearly 126 billion USD globally and employment contribution of cruise sector expenditures accounts for over 1 million employees, which indicates $7.6 \%$ and $6.8 \%$ rise respectively, compared to 2015. As for the cruise ship building industry, the total order book value is nearly 65 billion USD from 2018 through 2027 (Cruise Industry News, 2018)

In terms of environmental impacts, however, cruising is still receiving much criticism as one of the notorious means of travel. The major part of environmental impacts of cruise ships include air pollutions and particles, sea discharges such as ballast water, grey water, swage, noise pollution and solid waste (Andersson et al., 2016).

\section{Overview of Cruising Environmental Practices}

In response to concerns about environment and climate, cruise industry has undertaken notable actions. IMO (2018a): International Maritime Organization, which is the United Nations specialized agency responsible also for prevention of marine pollution by ships, states that thank to the contribution of the industry, currently, the maritime industry has the least environmental impact in comparison to other means of transport. CLIA (2018b) relates environmental practices and actions of cruise lines to the success of the industry and states that in tourism sector, cruise industry is the leader of environmental stewardship. CLIA cruise line members are committed to environmental policies and practices which may exceed international regulations such as zero discharge policy for untreated sewage, implementing advanced solid waste and waste water management systems. As for future scenario of the industry, energy efficiency and sustainability will shift to the top of the design priority list. As an example, CLIA cruise line members are investing 1 billion USD in development of environmentally-friendly technologies and fuel alternatives such as LNG (Liquefied Natural Gas) that 21 new built ships from 2018-2027 will be LNG powered. In addition, in cooperation with International Maritime Organization (IMO), CLIA develops compulsory measures for lowering CO2 emissions of new built ships by 30\% as of 2025 (CLIA, 2018b). Despite the promising progress of the industry in reducing environmental impacts, there is still a need for more effort to accelerate sustainability transition of the industry.

Sustainability improvements of cruise ships are mainly the result of two drivers: (1) Cruise lines' sustainability initiatives and actions, which include technological improvements, strategies and policies. For instance, Carnival Cruise Line commits to continuously improve the quality of air emissions by developing exhaust gas cleaning systems, resulting in the reduction of sulfur compounds (Carnival Corporation, 2018), and Royal Caribbean Cruises (2018) take the advantage of smart HVAC system that reduces cooling consumption by $25 \%$; (2) Stringent regulations that are increasingly applied to cruising sector, aiming to decrease the environmental footprints of ships. For example, as of January 2019, if the new vessel does not operate an approved sewage treatment plant, discharges in the Baltic Sea will be strictly banned (IMO, 2016). 


\section{Cruise Industry and Sustainable Development Goals (SDGs)}

The SDGs consist of 17 goals set by the UN in relation with the "2030 Agenda for Sustainable Development". The goals include a comprehensive range of social, economic and environmental issues in regard with people, planet, prosperity, peace and partnership (UN, 2018a). UN encourages business sectors and industries to respond to SDGs by firstly conducting business responsibility and then "pursue opportunities through innovation and collaboration" (UN Global Compact, 2018). Expectedly, one of the major principles highlighted by UN for industries is environmental protection.

In the framework of tourism industry, UNWTO (world tourism organization) has demonstrated the impact of tourism collaboration in realization of the SDGs, stating that "tourism has the potential to contribute directly or indirectly to all of the goals (UNWTO, 2017). Accordingly, cruising as a large segment of tourism industry can have significant potentials of contribution in achieving SDGs. In format of a booklet (2016) International Maritime Organization (IMO) addresses the contribution possibilities of maritime and shipping industry and highlights that different sectors of maritime including cruise industry are important enablers for the majority of the SDGs. Similarly, CLIA (2017b) announces the commitment of its cruise line members to the SDGs and as an example of partnership for the SDGs, UN reports that CLIA cruise members and SPTO (South Pacific Tourism Organization) have shown common interest and commitment to promote cruise tourism in the region and improve sustainable development of the region (UN, 2018b).

In a research conducted by DNV.GL, a classification society for enabling organizations to advance their sustainability, which works directly with maritime and cruising industry, the relevance of SDGs for shipping industry is studied and concluded that the industry has a critical role to play in meeting majority of goals (DNV.GL, 2017).

In response to Sustainable Development Goals, some directly and some indirectly, many of the cruise lines updated and reported their strategies and practices. For instance, Costa Cruise Line has directly referred to SDGs in its latest sustainability report (2017), and showed the commitment of the company to contribute to SDGs. Also TUI Group announces that the company including its cruise line is recognized by RobecoSAM researcher as one of the most sustainable tourism companies with remarkable contribution to SDGs (TUI, 2018). Disney Cruise Lines underlines the importance of their role in SDGs and notes that the company uses the SDGs as a guideline to inform their sustainability policies, practices and engagement (Disney Cruise Lines, 2017). On the other hand, some companies such as AIDA Cruises and Norwegian Cruise Line indirectly refer to SDGs in their sustainability and responsibility reports (AIDA, 2017; NCLH, 2017).

\subsection{Cruising and Goal 14 of the SDGs: Life Below Water}

Goal 14 of the SDGs comprises "Conserve and sustainability use of the oceans, seas and marine resources for sustainable development". This goal requires the stakeholders and participants to contribute to the following targets:

1. By 2025, prevent and significantly reduce marine pollution

2. By 2020, sustainability manage and protect marine and costal ecosystems to avoid significant adverse 


\section{impacts}

3. Minimize the impacts of ocean acidification, including through scientific cooperation

4. By 2020, effectively regulate harvesting and end overfishing

5. By 2020, conserve at least $10 \%$ of costal and marine areas

6. By 2020, prohibit certain forms of fisheries subsidies resulting in overfishing

7. By 2030, increase the economic benefits to small island developing states and least developed countries from the sustainable use of marine resources

Expectedly, contribution of tourism industry and cruising sector, in particular, to the SDG 14 is of crucial importance. UNWTO (2017) highlights the remarkable role of responsible tourism in achieving SDG 14 and declares the targets of tourism contribution in wildlife and ecosystem protection, pollution reduction, waste treatment, offsetting actions, green purchasing, increasing awareness and community involvement. IMO also emphasizes the importance of SDG 14 and demonstrates that SDG 14 is "central to International Maritime Organization (IMO, 2018b). In regard with SDG 14, IMO specifies its responsibility for measure to improve the quality of international shipping in variety of fields such as preventing pollution from ships, protecting maritime wildlife, underwater noise reduction from ships and preventing harmful discharges from ships.

DNV.GL study (2017) clarifies the role of shipping and cruising industry in regard with SDG 14, which has a direct effect on the achievement of goal. The study indicates that the shipping industry can contribute to SDG 14 in the following ways: (1) reducing discharges to sea such as ballast water, chemicals, waste, oil and sewage; (2) setting requirements for suppliers and ship builders within ship design and construction phase; (3) reducing air emissions which results in lowering ocean acidification; (4) setting regulations on biofouling; (5) committing to maritime regulatory and implement policies and innovative practices; (6) contributing in clean-up activities in the ocean and sea; (7) sharing knowledge and data throughout their operation about water conditions; and (8) reducing disturbance of marine life in terms of noise and protecting sensitive areas. CLIA also emphasizes the impact of cruise industry specifically on SDG 14, in the areas of ballast water management as well as sewage treatment and discharge (CLIA, 2017a).

\section{Method}

The major objective of the present study is to investigate how cruise industry responded to SDG 14 for conserving sea and water. The study is conducted in exploratory approach and research data in is drawn from cruise lines' official websites and publications in regard with sustainability, environmental practices and corporate responsibility. The cruise lines that are chosen for this study are selected based on two factors: (1) cruise line's passenger capacity and revenue (Cruise Market Watch, 2018b); (2) Availability of updated reports on corporate responsibility, sustainability or environmental initiatives. Given that, six cruise companies namely AID A Cruise Line, Carnival Corporation, Cosa Cruises, Norwegian Cruise Line, Royal Caribbean Cruises and TUI Cruises, were selected for this study. This research was conducted in June 2018 and the most recent reports and publications of the mentioned cruise companies were used as study materials. This study does not try to measure companies' initiatives for SDG 14, 
but merely to explore the available data communicated by cruise lines. Moreover, this research is based on selected information provided by cruise companies, thus the author does not have any responsibility in conducting fact-check and investigating the transparency of claimed data. Said that, this research seeks to address how cruise companies' respond to SDG 14 and communicate their initiatives with public.

To explore the response of cruise lines to SDG 14, this paper refers to the following targets of SDG 14 as DNV.GL (2017) suggests:

14.1. By 2025, prevent and significantly reduce marine pollution

14.2. By 2020, sustainability manage and protect marine and costal ecosystems to avoid significant adverse impacts

14.3. Minimize the impacts of ocean acidification, including through scientific cooperation

As DNV.GL study shows, the industry can have direct effect on these three targets which indicates the relevance of the targets to environmental initiatives and stewardships of cruise industry.

However, reviewing sustainability reports of cruise lines indicates that a large number of sustainability initiatives and practices of cruise companies can fit in more than one of the above mentioned targets. For example, waste water treatment initiatives reduce not only marine pollution (target 14.1) but also decreases the adverse impacts on marine ecosystem (target 14.2). For this reason, this paper does not categorize the sustainability practices of cruise lines into distinct three targets but chooses them according to the relevance of the practices and initiatives to SDG 14 targets. The author is aware of the limitations in the study and does not try to provide a detailed comparative analysis of sustainability practices of cruise lines. On the contrary, the paper is merely a preliminary attempt to review and compare the overall sustainability initiatives of cruise industry in response to SDG 14.

\section{Findings and Discussion}

Reviewing the sustainability and responsibility reports of selected cruise lines shows significant similarities in the approach of companies towards SDG 14 that can be divided into the followings:

(1) Energy efficiency, fuel and emission management (relevant to targets 14.1, 14.2, 14.3 for the direct effect on sea and ocean acidification);

(2) Water and wastewater management (relevant to targets 14.1, 14.2);

(3) Waste management (relevant to targets 14.1, 14.2);

(4) Biodiversity and ecosystem protection (mainly relevant to target 14.2).

Each of the mentioned initiatives is considered by leading cruise companies in variety of levels.

1- Energy efficiency, fuel and emission management:

In response to this category, selected cruise lines offer and report variety of initiatives and practices. AIDA emphasizes its commitment to reduce the energy consumption as well as CO2 emissions through different technologies such as use of dual fuel engines, heat recovery systems and energy consumption tracking and monitoring systems. AIDA Cruise Line announces to introduce the first and the second cruise ships in the world capable of using solely LNG (Liquefied Natural Gas) which is known to be an efficient 
source of power. In addition, the company is determined to develop cold ironing as well as studies on the use of fuel cells onboard for new ships. The latest report of AIDA, called AIDA Cares 2017 indicates that the company has been successful in achieving desired targets in reducing $\mathrm{CO} 2$ emissions and energy consumption, compared to previous years. Carnival Cruise Lines, which hold AIDA brand under its corporation, similarly reports the use of LNG as a remarkably successful initiate in energy efficiency, which results in the reduction of sulfur emission to 0 , carbon emission reduction by $25 \%$ and nitrogen oxides reduction by $85 \%$. The company reports its attempt to deliver considerably more energy efficient new ships by optimized hull design, waste-heat use system and use of energy efficient equipment onboard. Carnival also reports that $40 \%$ of their vessels are equipped with cold ironing capabilities and nearly 60\% of the ships are equipped with Exhaust Gas Cleaning Systems. The company also states its commitment to decrease intensity of $\mathrm{CO} 2 \mathrm{e}$ (equivalent carbon dioxide) emission from operation by $25 \%$ by 2020 , compared to 2005. Costa Cruise Line also belongs to Carnival Corporation, which in turn follows the major initiatives of the company. Costa reports its gradual transition from conventional fuels to LNG powered ones, implementing Exhaust Gas Cleaning systems, use of low sulfur fuels in emission control areas, installation of waste-heat recovery systems and use of automatic lighting control system. It is worth mentioning that Costa report is designed based on SDGs and the framework of the report is written in response to SDGs.

Norwegian Cruise Line stewardship shows the company's effort in energy and consumption efficiency in different ways such as biofouling management to improve hydrodynamics efficiency and lowering the consumption, energy efficiency data collection onboard to track the efficiency, lighting upgrade, use of new paint system for low friction coating, waste-heat recovery and exhaust gas cleaning system on a number of ships. Norwegian to the best of my knowledge, however, did not report initiatives towards alternative fuels such as LNG.

Royal Caribbean Line states the strategy of the company towards future generation of cruises which will be considerably more energy efficient through using technologies in LNG, fuel cells, use of air lubrication system that coats the underside of ship and reduces the friction, and advanced emission purification systems (exhaust scrubbers). The company also reports the use of smart HVAC (heating, ventilation and air conditioning) system which reduces cooling by $25 \%$. In terms of high-tech energy solutions, Royal Caribbean uses advanced energy management software which identifies ships' optimal balance, speed, route and the number of engines must be used including their settings.

TUI group published its sustainability report not only about TUI cruises but also other services of the company such as aviation and land trips. Nevertheless, the report is mainly based on SDGs and shows company's commitment, policy and practices towards achieving sustainable development goals. TUI's sustainability report 2017 indicates that the cruise sector of the company achieved 1.5\% more carbon efficiency improvements compared to 2015. TUI new built cruises combine different technologies such as smart energy management system, efficient air conditioning, lighting controls and use of engine waste heat to save fuel. TUI ships also use scrubber technology to treat exhaust fumes which results in nearly $99 \%$ lower sulfur emission in new-built ships. As the report states, 
TUI cruises minimized sulfur intensity by nearly 22\% in comparison to 2016.

2- Water and wastewater management:

Sustainability initiatives and practices of cruise lines in regard with water conservation and wastewater treatment showed notable similarity. All the selected cruise lines emphasized their approaches for the following practices: (a) Reducing water consumption onboard, for example Carnival encourages guests to reuse towels and uses low flow showers in cabins. Royal Caribbean uses special ice makers which consumes 65\% less water than previous ones and also re-uses clean condensate water from ship's air conditioning units in laundry areas. Onboard production of clean water from sea water is one of the main practices of all the cruise lines in different scales and methods; (b) $W$ aste water (grey water, black water and water from food waste) treatment, for example AIDA underlines the use of AWWPS (Advanced Waste Water Purification Systems) which produces "almost drinking water" quality. Costa also shows its improvement in wastewater in the report for a period of two years since 2014. The overview of the research in this area shows that all of the cruise lines meet or exceeds the requirements of water conservation and wastewater treatment. (c) Bilge water (wastewater collected in machinery and engine spaces) treatment, in a similar approach, all of the cruise lines are equipped with devices which analyses and separates the bilge water from any potential oil. The device automatically stops the discharge in the analysis does not meet the measures. (d) Ballast water (sea water brought to ship to help stabilization) treatment, cruise lines report their commitment to IMO Ballast Water Convention. Royal Caribbean as an example states that one of its vessels called Quantum of Seas was equipped with ballast water treatment system before the declaration of international requirements. Norwegian reports that all its new ships built as of 2013 were equipped with ballast water treatment system. All in all, due to the IMO regulation, all of the cruise lines are required to follow and implement the system accordingly.

3- Waste mitigation and management:

Despite the fact that all the cruise lines have their own way to handle waste generated onboard, the relevant part of waste management initiatives to SDG 14, include the ones which minimize waste discharges to water. In this particular topic, the selected cruise lines follow almost the same approach which includes separation of solid waste to be landed ashore, strategies to separate the waste onboard, and minimizing food waste. Donation is also a part of the policy of some cruise lines such as Royal Caribbean and Norwegian. AIDA as well as Carnival explain that according to regulations food waste is compressed and drained and as the by-product of the system is biologically degradable substance, will be partially delivered to certified disposal organizations and those food waste smaller than $25 \mathrm{~mm}$ are permitted to be discharged in the sea if outside the 12 milezone. Regarding waste regulations, cruise lines must follow the international MAPROL Convention which prevents pollution from ships. It should be emphasized that the present study does not confirm or deny the action of cruise lines as it is entirely depends on the transparency of the claims and actions of companies.

4- Biodiversity and ecosystem protection:

In this field cruise lines have conducted a large variety of initiatives in two categories. Firstly, they endeavor to participate in research projects, sustainability-related actions and communities, and biodiversity conservation practices. Secondly, cruise companies report 
their practices and plans towards saving the marine ecosystem as well as reducing the impacts on the wildlife and life under water. AIDA, for example, is a member of Futouris e.V. sustainability program, focusing on welfare of animals. The cruise line also increase awareness of sea life for passengers in different ways. In addition, AIDA tries to lower the fouling with underwater coating as well as regular hull cleaning to prevent foreign organisms to enter the sea. Carnival Corporation also reports its close cooperation with many research centers working on maritime ecosystems such as The Nature ConserVancy. Additionally, Carnival introduces and promotes its TravlDeep brand, Fathom (Responsible Cruising) as of 2016 that gives the guests the opportunity to be involved in local projects and cooperate with communities. Costa cruise has an agreement with CNR (Italian National Research Council) for long-term collaboration in the field of oceanography and marine science. In addition, Costa announces that one of its top priorities in regard with marine conservation is to protect the environment of Giglio Island in Italy in which a number of research organizations and academic centers are involved. As for Royal Caribbean initiatives, the cruise line provides a close collaboration with University of Miami's Rosenstiel School of Marine and Atmospheric Science, in order to operate labs onboard for ocean and climate related researches. To support the marine ecosystem, this cruise company contributed in a project with World Wildlife Fund (WWF) to increase awareness about shark and ray tourism. Norwegian Cruise Line, is also considerably active in conducting partnership with research and conservation programs for marine ecosystem. As an example, the company has developed policies to reduce the impact of operation on marine mammals (whales) through lowering the speed, keeping safe distance from them, training crews for sighting the whales and identifying the mammals. Norwegian, also, conduct cleanup activities while docking in selected ports to collect plastic waste from sea. As previously mentioned, the selected cruise lines have significant roles in ecosystem conservation projects as well as research projects, of which this paper named some of them.

\section{Conclusion}

The present exploratory study set out to determine sustainability initiatives and practices of major cruise lines in response to SDG 14, "life below water". As discussed, SDG 14 was underlined by different organizations related to maritime industry, as one of the main goal of SDGs on which cruise industry can have a significant impact. In this study we chose targets $14.1,14.2$ and 14.3 of SDG 14 due to the impact of cruising on them.

In the study, 6 cruise companies were selected and their latest sustainability, responsibility or stewardship reports were reviewed. The results of the study showed that all of the cruise lines (directly or indirectly) set their sustainability reports in response to UN's SDGs, and one of the most highlighted part of their report consisted of water, sea and ocean conservation. As reported the major initiatives of cruise lines in response to SDG 14 was focused on four topics including energy and fuel efficiency, water and wastewater treatment, waste management, and conservation of ecosystem. In regard with the first practice, cruise lines have taken considerable initiatives and actions to reduce the energy consumption and utilize alternative fuels and power sources. However, the 
majority of innovations and practices are implemented on newly-built ships while these technologies are not utilized on a considerable number of previously-built vessels on operation. Concerning water and wastewater treatment, cruise companies have conducted similar actions, for example, the use of wastewater treatment technologies, lowering water consumption and treating bilge water. In this particular topic, regulations and rules urge the cruise industry to conduct necessary practices which may explain the similarity of the practices done by companies. Also, in terms of waste management strategies and practices, cruising industry must be committed to certain regulations for waste handling to ashore and discharges to water. Reviewing the cruise lines' initiatives, the author suggests that despite the effort of the industry in waste management, there is still need for improvements in the following two: (1) regulations concerning waste handling and discharges to water; (2) providing more transparency from cruise lines in terms of promoting their effort and actions.

Partnership with research and ecosystem conservation projects was one of the highlighted initiatives of all the selected cruise lines. The efforts range from cooperation with individual researchers and collaboration with research projects, to cleanup and conservation of maritime ecosystem of a selected area. The present study suggests that sustainability-related efforts of selected cruise lines in this topic include variety of practices and initiatives. Taken together, the exploratory study of selected cruise lines indicates that the industry has responded to SDG 14 positively and conducted variety of practices and initiatives. Despite the exploratory nature, the author believes this study offers some insights into sustainability improvements of cruise industry in response to SDGs. Although the current study does not offer practical suggestions to improve cruise lines' practices in regard with SDG 14, it can provide an overview of the current situation of the industry and suggests that further researches can evaluate and compare the actual impact of the initiatives of each cruise line in terms of water and sea conservation.

\section{References}

Aguirre, S.Z., and Brida, J.G. (2008). The Impacts of the Cruise Industry on Tourism Destinations, Sustainable tourism as a factor of local development, Monza, Italy 7-9/11-2008

AIDA Cruise Line. (2017). AIDA Cares 2017: Sustainability report. Retrieved from: https://media.aida.de/fileadmin/user_upload/v4/Unternehmen/Nachhaltigkeit/Tabellen/2017/ AIDAcares_2017_-_EN_-_komprimiert.pdf

Andersson, K., Brynolf, S., Lindgren, J.F., and Wilewska-Bien, M. (eds.). (2016). Shipping and the environment. Berlin: Springer

Carnival Corporation. (2018). Sustainability from ship to shore. Retrieved from: http://carnivalsustainability.com/

CLIA. (2017a). The contribution of the international cruise industry to the global economy in 2016. Retrieved from: https://cruising.org/docs/defaultsource/research/global_economic_contribution_2016.pdf?sfvrsn=2

CLIA. (2017b). Cruise industry committed to United Nations' sustainable development goals. Retrieved from: https://globenewswire.com/news-release/2017/10/24/1152502/0/en/Cruise-Industry-

Committed-to-United-Nations-Sustainable-Development-Goals.html

CLIA. (2018a). Cruise industry outlook. Retrieved from: https://cruising.org/docs/defaultsource/research/clia-2018-state-of-the-industry.pdf?sfvrsn=2 
CLIA. (2018b). Environmental sustainability report. Retrieved from: https://www.cruising.org/about-theindustry/press-room/press-releases/clia-releases-environmental-sustainability-report

Costa Cruise Line. (2017). On course for the future: Sustainability report 2016 results and and outlook. Retrieved from: https://web.costacrociere.it/B2C/GuidelinesV5/sostenibilita/pdf/Costa_BdS_ENG_03.pdf

Cruise industry news. (2017). New cruise ship orderbook now 106 ships going 2027. Retrieved from: https://www.cruiseindustrynews.com/cruise-news/18668-new-cruise-ship-orderbook-now-106ships-going-to-2027.html

Cruise Market Watch. (2018a). Growth of the ocean cruise line industry. Retrieved from: https://www.cruisemarketwatch.com/growth/

Cruise market watch. (2018b). World cruise line passenger capacity. Retrieved from: https://www.cruisemarketwatch.com/capacity/
Cruise Lines. (2017). Corporate social responsibility update. Retrieved from:

Disney Cruise Lines. (2017). Corporate social responsibility update. Retrieved
https://www.thewaltdisneycompany.com/wp-content/uploads/2017disneycsrupdate.pdf

DNVGL. (2017). Sustainable development goals: exploring maritime opportunities. Retrieved from: https://www.rederi.no/globalassets/dokumenter-en/all/fagomrader/smi/dnv-gl-sdg-maritimereport.pdf

IMO. (2016). Annex10, resolution MPEC.275(69). Retrieved from: http://www.imo.org/en/KnowledgeCentre/IndexofIMOResolutions/Marine-EnvironmentProtection-Committee-\%28MEPC\%29/Documents/MEPC.275\%2869\%29.pdf

IMO. (2016). IMO and sustainable development. How international shipping and the maritime community contribute to sustainable development Retrieved from: http://www.imo.org/en/MediaCentre/HotTopics/Documents/IMO\%20SDG\%20Brochure.pdf

IMO. (2018a) , Marine environment. Retrieved http://www.imo.org/en/OurWork/Environment/Pages/Default.aspx

IMO. (2018b). IMO and Sustainable development goals. Retrieved from: http://www.imo.org/en/MediaCentre/HotTopics/Pages/SustainableDevelopmentGoals.aspx\#n umber14

Jones, P., Hillier, D., and Comfort, D. (2016). The Environmental, Social and Economic Impacts of Cruising and Corporate Sustainability Strategies. Athens Journal of Tourism. 3(4). 273-285

NCLH: Norwegian Cruise Line Holdings LTD. (2017). Stewardship report. Retrieved from: http:// files.shareholder.com/downloads/ABEA-5WOY6H/4353190173x0x938799/EE369DF09BDD-482E-BBD5-5002D5E0CACE/Final_Environmental_Report_for_Distribution_4.24.2017.pdf

Royal Caribbean. (2018). The commitment to oceans. Retrieved from: http://sustainability.rclcorporate.com/

TUI Group. (2018). Recognition for TUI group's sustainability strategy. Retrieved from: https://www.tuigroup.com/en-en/media/stories/2018/2018-02-06-recognition-for-tui-groupssustainability-strategy

UN Global Compact. (2018). Global goals for people and planet. Retrieved from: https://www.unglobalcompact.org/sdgs/about

UN: United Nations. (2018a). Transforming our world. Retrieved from: https://sustainabledevelopment.un.org/post2015/transformingourworld

UN: United Nations. (2018b), Cruise tourism development. Retrieved from: https://sustainabledevelopment.un.org/partnership/?p=7708

UNWTO. (2017). Tourism and the Sustainable Development Goals: Journey to 2030, Highlights, UNWTO, Madrid. DOI: $10.18111 / 9789284419340$ 